\title{
COVID-19 and Neurosurgery: Time for Triage
}

\author{
Kiran Jangra ${ }^{1, \odot ~ S h a s h a n k ~ P a l i w a l ~}{ }^{1}$ Manjul Tripathi ${ }^{2}$ \\ ${ }^{1}$ Department of Anaesthesia and Intensive Care, Postgraduate Institute \\ of Medical Education and Research, Chandigarh, India \\ ${ }^{2}$ Department of Neurosurgery, Postgraduate Institute of Medical \\ Education and Research, Chandigarh, India
}

J Neuroanaesthesiol Crit Care 2020;7:67-69

The novel coronavirus has emerged as a pandemic, which is now prevalent across the entire globe. This is a highly virulent virus that spreads rapidly through contact with droplets of infected patients. The disease caused by this virus is often referred to as COVID-19. The major step of stopping the spread of this virus is social distancing (at least 6 feet) and limited mobility of human beings. Hence, various countries have implemented curfew or lockdown to prevent the spread.

COVID-19 rapidly involves and affects respiratory and cardiovascular systems primarily, and the patients may need ventilatory support. There are a few case reports of involvement of central nervous system where patients presented with seizures or encephalitis along with respiratory distress. ${ }^{1,2}$ The effect of this disease on brain and spinal cord is not known but there are a few concerns regarding neurosurgery during this disease. The lockdown has also proven advantageous for neurosurgery, as the number of traumatic injuries has drastically decreased.
Address for correspondence Kiran Jangra, DM, Department of Anaesthesia and Intensive Care, 4th floor, Nehru Hospital, Postgraduate Institute of Medical Education and Research, Chandigarh 160012, India (e-mail: drkiransharma0117@gmail.com).

COVID-19 poses a huge burden on the economy due to lockdown. At the same time, the hospitals have run out of resources due to the huge burst of patients. To decrease the spread and reserve the hospital resources to deal with the pandemic, it is very much desirable that only emergency cases should be operated upon. It is very difficult to triage patients with neurological disorders. There are a few published guidelines to deal with this issue that is discussed in this manuscript.

One of these guidelines is published by the American College of Surgeons and Center for Medicare and Medicaid Services to prioritize the surgical patients. ${ }^{3}$ They described three tiers of surgical acuity, and each tier is further subdivided into levels, depending on the overall health of the patient (-Table 1). The tier-1 includes surgeries with low-acuity where illness is not life-threatening. The tier-2 includes surgeries with intermediate acuity where illness is not life-threatening but have a potential for the future

Table 1 Guidance for triage of the adult surgical procedures

\begin{tabular}{|l|l|l|l|}
\hline Category & & Examples of pathologies & Recommendation \\
\hline Tier-1 & Low-acuity treatment or service & Cosmetic surgeries/elective surgery & $\begin{array}{l}\text { Neurosurgeries do not fall in this } \\
\text { category }\end{array}$ \\
\hline Tier-2 & $\begin{array}{l}\text { - Intermediate acuity treatment } \\
\text { or service } \\
\text { Not life-threatening but } \\
\text { potential for causing severe } \\
\text { disability if not treated in time }\end{array}$ & $\begin{array}{l}\text { - Slow growing spinal cord tumors or } \\
\text { noneloquent intracranial tumors }\end{array}$ & Postpone the procedure, if possible \\
\hline Tier-3 & $\begin{array}{l}\text { High-acuity treatment or } \\
\text { service }\end{array}$ & $\begin{array}{l}\text { Immediately life-threatening } \\
\text { - Acute trauma } \\
\text { Intracranial bleed } \\
\text { Space-occupying lesion with } \\
\text { significant midline shift } \\
\text { Lesions causing deterioration in } \\
\text { conscious level }\end{array}$ & $\begin{array}{l}\text { Proceed without delay as long as } \\
\text { resources are available }\end{array}$ \\
\hline
\end{tabular}

DOI https://doi.org/ $10.1055 / \mathrm{s}-0040-1712816$ ISSN 2348-0548.
(C)2020 Indian Society of Neuroanaesthesiology and Critical Care
License terms

()(1) $\Theta \circledast$ 
morbidity and mortality, and requires an in-hospital stay. The tier-3 includes surgeries with high-acuity, which cannot be postponed. The degree of urgency of the surgery should always be decided by the surgeon after discussing risks of doing or delaying the surgeries with the patients or their family. There are various neurosurgical emergencies, including cerebral hemorrhages (subarachnoid and intraparenchymal), acute hydrocephalus, intracranial lesion with significant mass effect, spinal cord lesions causing cord compressions, and traumatic brain and spinal cord injuries. These surgeries fall in tier-3 category and need to be operated as early as possible.

There are a few neurosurgical procedures that might place the surgeons and other staff at greater risk of acquiring COVID-19 due to the generation of aerosols such as trans-sphenoidal surgeries. Hence, it is advisable to cancel the elective cases for, at least, one month. In urgent cases (large tumor, threatening the vision), two COVID-19 tests should be performed, 24 hours apart, keeping the patient in quarantine until both the tests are completed. The surgery should be proceeded only if both the tests are negative. If unavoidable (or emergent such as pituitary apoplexy) situation arises, in patients positive for COVID-19 or in undetermined status, the entire operation theater personnel should use the standard personal protective equipment (PPE). Another reasonable approach is to proceed through a transcranial approach instead of the transnasal approach, if possible.

Zoia et al described another classification to triage the patients for oncological neurosurgery in the COVID-19 pandemic. ${ }^{4}$ The author described three classifications including class $\mathrm{A}^{++}$, class $\mathrm{A}+$, and class $\mathrm{A}(\boldsymbol{\sim}$ Table 2 ). In class $\mathrm{A}++$, the patients require immediate treatment. The class $\mathrm{A}+$ patients may require early treatment, may be within a maximum of 7 to 10 days, and the class A patients may require treatment within a month. The class A++ patients should be managed like other surgical emergencies, while the other two classes should be managed according to clinical priorities and available resources.

It is very important to triage the cases for surgery to conserve the hospital resources, as the difficult time is yet to arrive. We have to ensure the minimum exposure of healthcare providers as no one is immune to COVID-19. There have been many instances where COVID-19 has affected the healthcare providers. Recently, the famous neurosurgeon, Dr. Ezriel Kornel, who is at the forefront of minimally invasive neurosurgery (MIS) with Brain \& Spine Surgeons of New York, also got infected while examining one infected patient. We express deep condolences for the departed souls of famous neurosurgeons due to COVID-19, including Commodore Jeanne P. M. R. Winaktu (first female neurosurgeon in Indonesia), James T. Goodrich (Director of Pediatric Neurosurgery at Albert Einstein College of Medicine; Morris Park, Bronx, NY, USA), Dr. Liu Zhiming (Medical College of Wuhan University; Wuhan, China), and Dr Simon Hercules (Managing Director; New Hope Hospital, Chennai, India).

We truly hope that this pandemic should end soon, but to protect healthcare providers, the exposure to the patients should be minimized, and appropriate triage guidelines should be formulated as per local logistics. We have proposed the Adaptive Neurosurgery Acuity Scale for the Indian scenario (-Table 3 ). Triaging the cases, minimizing the exposure, using personal protection, and staying safe is the priority.

Table 2 Priority criteria for oncological pathology

\begin{tabular}{|l|l|l|}
\hline Category & Pathologies & Recommendation \\
\hline A++ & $\begin{array}{l}\text { Intracranial or spinal oncological pathology causing } \\
\text { - Rapidly evolving intracranial hypertension with deteriorating state } \\
\text { of consciousness } \\
\text { - Acute hydrocephalus } \\
\text { - Acute spinal cord compression with rapid tetra or paraparesis }\end{array}$ & Requires immediate treatment \\
\hline A+ & $\begin{array}{l}\text { Intracranial tumors } \\
\text { - with mass effect } \\
\text { - with progressive neurological deficit } \\
\text { without deterioration of consciousness }\end{array}$ & $\begin{array}{l}\text { Requires treatment within a maxi- } \\
\text { mum of } 70 \text { days }\end{array}$ \\
\hline A & $\begin{array}{l}\text { Pathology that appears to be of suspected malignant nature on } \\
\text { radiology } \\
\text { or with oncological pathology that determines a neurological } \\
\text { deficit }\end{array}$ & $\begin{array}{l}\text { Requires treatment within a } \\
\text { month }\end{array}$ \\
\hline
\end{tabular}


Table 3 Proposed adaptive neurosurgery acuity scale in Indian scenario

\begin{tabular}{|c|c|c|}
\hline Category & Examples (not limited to) & Recommendation for surgery \\
\hline $\begin{array}{l}\text { Emergent cases } \\
\text { (high acuity) }\end{array}$ & 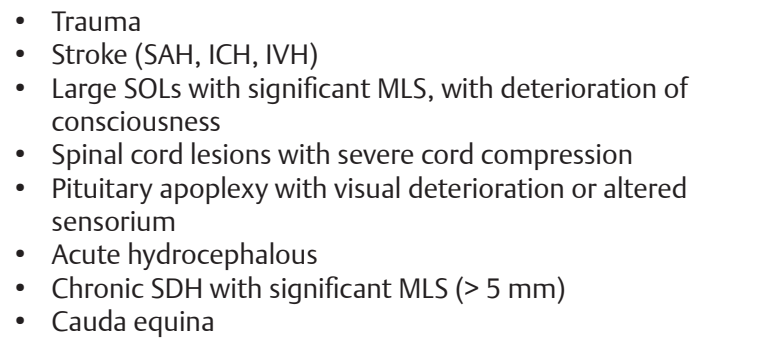 & $\begin{array}{l}\text { - Operate urgently } \\
\text { - Wear standard PPEs if symptomatic or } \\
\text { any significant history (international } \\
\text { visit/contact with infected/HCWs } \\
\text { working in COVID-care units) }\end{array}$ \\
\hline $\begin{array}{l}\text { Urgent cases } \\
\text { (high acuity) }\end{array}$ & $\begin{array}{l}\text { - Large SOLs without deterioration of consciousness } \\
\text { - Malignant brain and spine tumors } \\
\text { - Posterior fossa lesions } \\
\text { - } \text { Spinal cord lesions without cord compression } \\
\text { - } \text { Lesions lying near eloquent areas } \\
\text { - } \text { Pituitary lesions with constant threat to vision } \\
\text { - Pronic SDH without significant MLS (<5 mm) } \\
\text { - Complete preganglionic brachial plexus injury }\end{array}$ & $\begin{array}{l}\text { - Patients must be screened for } \\
\text { COVID-19 before surgery }\end{array}$ \\
\hline $\begin{array}{l}\text { Nonurgent cases } \\
\text { (intermediate acuity) }\end{array}$ & $\begin{array}{l}\text { - Symptomatic benign intracranial lesions without local or } \\
\text { - } \text { Leneralized mass effect } \\
\text { - } \text { DBS for progressive parkinsonism } \\
\text { - } \text { Refractory epilepsy } \\
\text { - Spontaneous disc prolapse without significant neuronal } \\
\text { - } \text { Sompression } \\
\text { - Unrull pituitary lesions with no mass effect } \\
\text { - } \text { Arteriovenous malformation } \\
\text { - Craniosynostosis } \\
\text { - Partial brachial plexus injury }\end{array}$ & $\begin{array}{l}\text { - Should be postponed, if possible } \\
\text { - Must screen before surgery if being } \\
\text { operated }\end{array}$ \\
\hline $\begin{array}{l}\text { Nonurgent cases } \\
\text { (low acuity) }\end{array}$ & $\begin{array}{l}\text { - Peripheral nerve surgery (e.g., carpal tunnel release) } \\
\text { - Benign intracranial tumors (asymptomatic or mildly } \\
\text { symptomatic) } \\
\text { - } \text { Microvascular decompression of cranial nerves } \\
\text { - Deep brain stimulation } \\
\text { - } \text { Degenerative spinal pathology (lumbar stenosis and spinal } \\
\text { - Gamma knife radiosurgery }\end{array}$ & - Postpone the surgery \\
\hline
\end{tabular}

Abbreviations: DBS, deep brain stimulation; HCW, healthcare worker; ICH, intracerebral hematoma; IVH, intraventricular hematoma; MLS, midline shift; PPE, personal protection equipment; SAH, subarachnoid hemorrhage; SDH, subdural hematoma; SOL, space-occupying lesion.

\section{Conflict of Interest}

None declared.

\section{References}

1 Filatov A, Sharma P, Hindi F, et al. Neurological complications of coronavirus disease (COVID-19): encephalopathy. Cureus 2020;12(3):e7352

2 Yeh EA, Collins A, Cohen ME, Duffner PK, Faden H. Detection of coronavirus in the central nervous system of a child with acute disseminated encephalomyelitis. Pediatrics 2004;113(1 Pt): e73-e76
3 American College of Surgeons. COVID 19: Elective Case Triage Guidelines for Surgical Care. Available at: https://www.facs. org/covid-19/clinical-guidance/elective-case/neurosurgery. Accessed March 24, 2020

4 Zoia C, Bongetta D, Veiceschi P, et al. Neurosurgery during the COVID-19 pandemic: update from Lombardy, northern Italy. Acta Neurochir 2020. Doi: 10.1007/s00701-020-04305-w 